\title{
1. International commercial contracts: autonomy and regulation in a dynamic system of merchant law
}

\author{
Andrew Hutchison and Franziska Myburgh
}

\section{INTRODUCTION}

This book deals with contract law and commercial practice on the international plane. The various chapters have been written by legal scholars from around the world, with the intention of shedding new light on an existing field of inquiry for both scholars and practitioners. The specific contribution of this book is that it locates international commercial contracting both historically, with reference to the lex mercatoria of European - and indeed world - commercial law history, ${ }^{1}$ and simultaneously with reference to current international practice. An important linking theme in this inquiry is the all important aspect of 'private ordering', ${ }^{2}$ thought by many to be a key feature to consider when regulating commercial contracts outside of the consumer sphere. By gathering the perspectives of various countries, which together represent a wide variety of national paradigms and trading contexts, this book aims to provide a balanced view of the focal topics. In the remainder of this opening chapter, we set out the core research concept of this handbook, as well the methodology of its compilation. Thereafter we address our connecting themes in more detail.

\section{CORE RESEARCH CONCEPT: DYNAMIC MERCHANT TRADITIONS}

In the classical sense, contracts are viewed as the law which parties make themselves to govern their relationship. ${ }^{3}$ The principle of freedom of contract enshrines the idea that parties are free to contract as they see fit, subject only to the requirements of legality and public policy. The rise of consumer law in the twentieth century has seen a division of the law of contract in most

1 This concept is defined below in section 4.1 with reference to historical sources. It is invoked largely in a symbolic sense there, however, in order to demarcate the rise of the law of commercial contracts in European trade and to demonstrate further the historic pedigree of the merchant ordering concept and its antithesis of State regulation.

2 This is a socio-legal concept, often used to describe how market participants construct their own social order (from the bottom up), rather than relying on the ordering of the central State (from the top down). The link to theories such as legal pluralism is inherent in this concept, since 'private ordering' describes norms which may exist outside of the State apparatus and in competition therewith. See further section 4.2 below.

3 Compare the general introduction set out by $\mathrm{K}$ Zweigert and $\mathrm{H}$ Kötz, An Introduction to Comparative Law (Tony Weir tr, 3rd edn, OUP 1998) 324-27. The classic work on freedom of contract from an English perspective is PS Atiyah, The Rise and Fall of Freedom of Contract (OUP 1979). 


\section{Research handbook on international commercial contracts}

countries into a branch which governs contracts where the interests of weaker parties need to be protected (business-to-consumer, or B2C contracts), and a branch governing commercial or business-to-business (B2B) contracts, where parties are given far greater autonomy to choose their own terms to govern their relationship. Most merchant contracts will fall into the latter B2B category. ${ }^{4}$ At an international level, the globalisation of trade and other business dealings has meant that merchant contracts will involve the selection of both a substantive legal regime and the forum in which a potential dispute will be heard. This process of merchant contracting thus contains the seed for a high degree of party autonomy, with the resultant ability to privately order a relationship through mutual agreement. This book starts from the premise that this degree of autonomy is the norm in merchant transactions, and that international commercial contracts should thus be viewed largely as private ordering devices.

This type of private ordering has long characterised international trade, at least if one subscribes to the governing historical narrative of the lex mercatoria. ${ }^{5}$ Although there is some debate about the historical accuracy of aspects of this narrative, what is clearly not a myth is the increase in the volume and complexity of international trade during medieval times and thereafter, and the concomitant development of substantive merchant (and State) norms to govern such practice. This is the history of commercial law and describes (inter alia): the origins of modern insurance law and the rise of the insurance industry; the development of bills of exchange and increasing sophistication of banking law and practice; and the evolution of customs governing merchant sales and the shipping of goods.

As commercial relationships evolved around the world, so the law needed to expand to keep up with long distance trade. In the sense that this label 'lex mercatoria' describes this gradual evolution, there is an element of tradition here that reflects the long history of the various branches of modern commercial contract law. A key theme of this book is thus 'dynamic tradition', signalling both an historical way of ordering business relationships and the continuing adaptability of such ordering devices to a changing world.

A further premise is that the merchant norms of the parent legal systems of Europe subsequently found their way into other world legal systems as trade routes globalised, making the lex mercatoria the commercial law history not only of Europe, but also of many other parts of the contemporary world. ${ }^{6}$ Social change, technological advance and continual increase in the globalisation of economic activity are a given; we ask here whether the basic building blocks of merchant contract law evolve with the system, or whether they remain largely unchanged as rules located in tradition and divorced from contemporary social and economic conditions.

Returning to the private ordering controversy in historical sources: we view private ordering in commercial contracts as being in many ways an ideal of laissez-faire commercial practice, which must always exist in antithesis to the need to invoke the substantive rules and procedural machinery of a given domestic state to enforce a contract. This is the political question of

\footnotetext{
4 This would exclude those merchants who may be classed as consumers under a particular national regime.

5 Private ordering is often said to be a key characteristic of the lex mercatoria narrative. See eg Emily Kadens, 'The Medieval Law Merchant: The Tyranny of a Construct' (2015) 7 JLA 251, 252 who expressly uses this terminology. The idea of merchant disputes being heard according to merchant procedures and being governed by merchant norms is expanded upon in section 4.1 below.

${ }^{6} \quad$ In support of this claim, see James Gordley, The Philosophical Foundations of Modern Contract Doctrine (OUP 1991) 1, who argues that following the enactment of the Chinese Civil Code, systems of private law based on those originating in Western Europe govern nearly the entire world.
} 
regulation, the nature and extent of which will vary from country to country and will evolve as commercial practice evolves. This long-existing dialectic shapes evolving traditions, in our view.

As for the substantive content of modern international commercial contract law, there are of course many choices of law available to parties operating in the transnational realm today. These include both popular domestic systems, such as the English Common Law of contract, as well as supra-national model rules, such as the United Nations Convention on the International Sale of Goods, ${ }^{7}$ the International Institute for the Unification of Private Law (UNIDROIT) Principles of International Commercial Contracts, ${ }^{8}$ or the European Commission Proposal on a Common European Sales Law. ${ }^{9}$ In addition, there are the various international instruments governing dispute resolution procedures, which are another important part of this picture. Berger labels this development the 'New Lex Mercatoria' ${ }^{10}$ For us, this terminology reflects the continuity of contexts which characterises merchant law past and present. Our question is: to what extent do things change in commercial contract law, and to what extent do they stay the same?

\section{METHODOLOGY: CHAPTER FRAMEWORK AND MANDATE TO AUTHORS}

In this book our aim is to provide research direction on commercial contract norms in a variety of merchant contexts, testing to see whether international commercial contracting differs between different jurisdictions. There is also a chapter dedicated to choice of law provisions specifically to address the private ordering element of dispute resolution. The result is a compilation of international perspectives originating from the US, England, continental Europe and Africa.

We have divided the book into several broad categories, namely: general principles of contract law (including choice of law provisions); merchant contract forms (dealing with specific contracting regimes); and new frontiers (specifically focusing on the digitalisation of commercial transactions in the contemporary and future eras). Within each category, we have selected certain key points, such as the role of good faith within the commercial contracting context, and remedies for breach (from general principles); sale and insurance (from merchant forms); online contracting, and smart contracts (from new frontiers). Appropriate authors were then selected for each topic, with a mix of both experienced researchers and fresh voices. Authors were requested to write on one of these specific topics, but with the topic left very broadly defined (as above) for the author to define further him or herself.

In addition, we stipulated a broad connecting theme for authors to bear in mind when framing a topic: namely, the dynamic traditions of merchant law, with particular emphasis

7 UN Convention on the International Sale of Goods (Vienna, 11 April 1980) 1489 UN Treaty Series 3, entered into force 1 January 1988.

8 The text of all four editions of the PICC is available at $<$ www.unidroit.org/instruments/commercial -contracts/unidroit-principles-2016> accessed 18 May 2020.

9 EC, 'Proposal for a Regulation of the European Parliament and of the Council on a Common European Sales Law' COM (2011) 635 final, 2011/0284 (COD).

10 Klaus Peter Berger, The Creeping Codification of the New Lex Mercatoria (2nd edn, Wolters Kluwer 2010). 


\section{Research handbook on international commercial contracts}

on the question of merchant private ordering and the extent to which this was or is facilitated by the relevant legal regime(s). We mentioned the lex mercatoria as a source of this type of commercial law narrative. Beyond this, some further instructions were given to certain authors, particularly where we specifically wanted a more historical focus, or a more location-orientated one (such as the history of English marine insurance law or commercial contract practice in the USA). The key general instruction given in common to each of the authors was to consider the following issues when framing their topic:

1. The governing law in the legal regime(s) of the assigned commercial topic;

2. Contemporary issues in the focal area which relate to the practice of modern commerce;

3. The extent to which such issues have always existed (since the historic lex mercatoria) or are a modern development affecting contemporary commercial merchants;

4. The extent to which merchants retain control of the focal theme;

5. The extent to which there may have been mutation of legal norms or practice over time and the reasons for this, confirming or denying the catchphrase 'dynamic tradition';

6. Proposed directions for the future development of the legal focal point assigned, in order to better reflect merchant practice; or why the law should not do this, if the author so believes;

7. The extent to which 'private ordering' is a desirable or obtainable goal in the focal area.

The result is the collection before you, of which we have provided an overview in this brief introductory chapter. Before the chapters commence, however, we will set out in a little more detail exactly what we mean by the two core concepts which form the linking themes of this book, namely (a) lex mercatoria and (b) private ordering in commercial contracting.

\section{LINKING THEMES}

\subsection{Lex Mercatoria}

The medieval lex mercatoria narrative often provides a somewhat romanticised historical account of commercial law norms, usually located in Western Europe and dated to the period between around $1000 \mathrm{AD}$ and $1500 \mathrm{AD} .{ }^{11}$ The conventional description deals with the expansion of trade during this period, first at markets and fairs in regional European centres - such as Champagne or Flanders - and then later moving to the emergent cities - such as Bruges, Antwerp, and London. ${ }^{12}$ The role of Italian merchants tends to receive special mention, since in this era Italian trade customs were more sophisticated and developed than in other parts of Europe. ${ }^{13}$ Thus we hear of Italian merchant customs governing bills of exchange, insurance, banking, insolvency, agency and suretyship spreading to other parts of Europe through the processes of regional and international trade between various European centres. ${ }^{14}$ These commercial devices were essential not only in facilitating long distance trade, but also in allowing for executory contracts and the all important aspect of credit, fundamental to the growth and development of business practices. A further key part of the traditional lex mercatoria

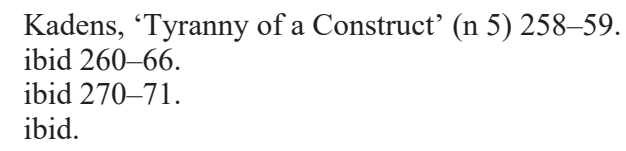


narrative is that disputes between merchants were resolved speedily in order to accommodate the profit-driven timelines of commercial activity, frequently in dedicated merchant forums rather than in the conventional courts. ${ }^{15}$ In sum, this version of legal history reveals a merchant-orientated system, developed by merchants themselves in accordance with trade customs and privately ordered according to merchant norms by specialist merchant courts.

The main sources of the lex mercatoria narrative are relatively well known. For present purposes only a few highlights will be mentioned. First is the key text of Englishman Gerard Malynes in his seventeenth-century account Consuetudo vel Lex Mercatoria, which described the origins of commercial law along the lines set out above and labelled this the development of a 'lex mercatoria'. ${ }^{16}$ Earlier evidence can also be found in the Italian Benvenuto Stracca's De Mercatura, although some argue that this work focuses more on the ius commune than specifically merchant law. ${ }^{17}$ An influential nineteenth-century account was that of German legal historian Levin Goldschmidt's Handbuch des Handelsrechts. ${ }^{18}$ Shortly thereafter, the lex mercatoria story was popularised in the early twentieth-century work of the British legal historian William Mitchell entitled An Essay on the Early History of the Law Merchant. ${ }^{19}$ The tradition was given a further romanticised twist in the account of Wyndham Bewes, aptly titled The Romance of the Law Merchant. ${ }^{20}$

A number of modern legal historians of the later twentieth century and the contemporary era have, however, attacked the lex mercatoria narrative as a 'myth'. ${ }^{21}$ In 1979, Baker challenged the story from an English point of view, arguing that there was no substantive law of contracts separate from the Common Law in the lex mercatoria; rather, it was simply a process for the speedy resolution of commercial disputes. ${ }^{22}$ In a more recent attack, Kadens points out that contract enforcement would not have been possible without the apparatus of the State, as well

15 Charles Donahue Jr, 'Medieval and Early Modern Lex Mercatoria: An Attempt at the Probatio Diabolica?' (2004) 5 Chi J Int'1 L 21, 36, citing Levin Goldschmidt, Handbuch des Handelsrechts (Enke 1891 ) as a source of this account. JH Baker, 'The Law Merchant and the Common Law before 1700' (1979) 38 CLJ 295, 296 states that this was the case in England prior to 1600, with merchant disputes heard in the Borough and Piepowder courts and the Court of Admiralty. The essence of the streamlined nature of civil litigation in disputes involving merchants, at least in the Piepowder courts, is captured in Blackstone's observation that ' $[\mathrm{t}]$ he lowest, and at the same time the most expeditious, court of justice known to the law of England is the court of piepoudre ... so called from the dusty feet of the suitors; or according to Sir Edward Coke, because justice is there done as speedily as dust can fall from the foot'. $3 \mathrm{Bl}$ Comm 32, citing E Coke, The Fourth Part of the Institutes of the Laws of England: Concerning the Jurisdiction of the Courts (London 1644) 272.

16 Gerard Malynes, Consuetudo vel Lex Mercatoria (London 1622).

17 Benvenuto Stracca, De Mercatura (Venice 1553). For discussion, see: Donahue (n 15) 27; Ralf Michaels, 'The True Lex Mercatoria: Law beyond the State' (2007) 14 Ind J Global Legal Studies 447 , 454.

18 Goldschmidt (n 15).

19 William Mitchell, An Essay on the Early History of the Law Merchant (CUP 1904).

20 Wyndham Bewes, The Romance of the Law Merchant (Sweet \& Maxwell 1923).

21 Baker (n 15); Oliver Volckart and Antje Mangels, 'Are the Roots of the Modern Lex Mercatoria Really Medieval?' (1999) 65 South Econ J 427; Donahue (n 15); Emily Kadens, 'The Myth of the Customary Law Merchant' (2012) 90 Tex L Rev 1153; Kadens, 'Tyranny of a Construct' (n 5). See, however, Leon E Trakman, The Law Merchant: The Evolution of Commercial Law (Fred B Rothman \& Co 1983), who supports the narrative.

22 Baker (n 15) 301. See also Albrecht Cordes, 'The Search for a Medieval Lex Mercatoria' [2003] Oxford U Comparative L Forum text to fns 21-28<https:/ouclf.iuscomp.org/the-search-for-a-medieval -lex-mercatoria/> accessed 18 May 2020, who explains that the term 'lex mercatoria' first appeared in 


\section{Research handbook on international commercial contracts}

as the fact that foreign traders were often far less warmly received in the various regional centres than the conventional narrative makes out, and were usually forced to submit to local customs and legal procedures in order to ply their trade. ${ }^{23}$ Similarly, Volckart and Mangels argue that trade and contract enforcement were only possible through the agency of powerful guilds in the early lex mercatoria period, and thereafter, with the rise of city infrastructure, through the agency of local authorities. ${ }^{24}$ These accounts undermine much of the narrative around internationally recognised customs and the all important aspect of privately ordered merchant dispute resolution. Indeed, Donahue suggests somewhat cynically that part of the aim of the early twentieth-century British accounts may have been an attempt to create a narrative celebrating commerce and commercial law in an era in which business persons had less status in society than they do today. ${ }^{25}$

Kadens does, however, take a more positive view of merchant ordering of the later modern era, using English legal history specifically as a narrative vehicle. ${ }^{26}$ The key reference here is to the agency of Lord Mansfield in the eighteenth century, whose tenure as Chief Justice in England came after both the merchant practices of Italians on Lombard Street in London had begun to catch on in England, ${ }^{27}$ and the recognition of the action of assumpsit had simplified the procedures of contract enforcement in the Common Law. ${ }^{28}$ Indeed, Lord Mansfield is generally given the credit for introducing increased levels of merchant practice into the English Common Law, ${ }^{29}$ in well-known judgments such as Luke $v$ Lyde, ${ }^{30}$ on the law of the sea, and Carter $v$ Boehm ${ }^{31}$ on good faith in insurance law. These are key relics of a period of British commercial expansion and illustrate how expanding trade customs became normatively binding and indeed part of the Common Law. In addition, Lord Mansfield introduced the use of commercial jurymen or assessors in order to provide expert advice on merchant disputes in the general courts. ${ }^{32}$ In sum, the commercial law of the early modern era in England rings fairly true with the general lex mercatoria narrative of a merchant-ordered system. Indeed, Trakman simply refers to the developments of this period as the 'modern Lex Mercatoria', citing in addition examples from other European countries. ${ }^{33}$

The aim of this recounting of the narrative, however, is not to resolve the debate about the historical accuracy of the lex mercatoria depicted in the traditional accounts, whether in the earlier medieval or the later modern period. This book focuses instead on continuing traditions in the substantive law itself, many of which have arisen over time during the course of the development of modern commercial law. Some of the practices described in this collection

The Little Red Book of Bristol (ca 1280) and that it was specifically reserved to describe the procedural privileges afforded to merchant litigants in English law in the thirteenth century.

23 Kadens, 'Tyranny of a Construct' (n 5) 260-66.

24 Volckart and Mangels (n 21) 437-46.

25 Donahue (n 15) 22-23.

26 Kadens, 'Tyranny of a Construct' (n 5) 256; Trakman (n 21) 27-28.

27 See eg: David Ibbetson, 'Law and Custom: Insurance in Sixteenth-Century England' (2008) 29 JLH 291, 292; Guido Rossi, 'The Booke of Orders of Assurances: A Civil Law Code in 16th Century London' (2012) 19 MJ 240.

28 Baker (n 15) 296.

29 Kadens, 'Tyranny of a Construct' (n 5) 256, Baker (n 15) 297.

30 (1759) 2 Burr 882, 97 ER 614.

31 (1766) 3 Burr 1905, 97 ER 1162.

32 Trakman (n 21) 28; Baker (n 15) 297.

33 Trakman (n 21) ch 2. 
have a far more recent pedigree than the historic lex mercatoria. The invocation of this concept is thus not necessarily intended to refer only to strict historical details, but rather to the ideal which underlies it, namely that merchant custom should drive the development of commercial law. Or, to put it slightly differently,

the medieval origins of the modern lex mercatoria serve as a 'foundation myth.' ... A foundation myth smacks of irrationality, but there is a rational counterpart: the medieval lex mercatoria as a thought experiment. To some extent, that seems to be what libertarians have in mind when they invoke a medieval lex mercatoria as a pure private governance. It is not intended as a description of how things actually were, but an imagination of how things could have been. ${ }^{34}$

In other words, '[h]istorians may aim at describing the actual middle ages to show how things actually were in the past. Proponents of a new lex mercatoria, by contrast, aim at invoking utopias of an imagined middle ages to show how things actually could and should be in the present. ${ }^{35}$ Since this book starts from the premises that there are indeed traditions in commercial law, that these arise both from merchant practice and otherwise, and that some of these traditions have considerable historical pedigree, we wish to draw on the spirit of the medieval lex mercatoria account, rather than on exact historical details.

In further defence of our methodology, we point to the fact that the concept 'lex mercatoria' is frequently used by authors describing the field of international commercial contracts law. This is the method of Trakman's well-known account, which uses an historical overview of the law merchant in order to set up a discussion of contemporary international commercial law. ${ }^{36}$ Similarly, the argument of Berger, alluded to above, is that there is a 'New Lex Mercatoria' in the contemporary era, ${ }^{37}$ which in many ways reflects the privately ordered, supra-national spirit of the romanticised historical accounts. In accordance with common practice, then, we invoke the concept in order to use commercial law history as a vehicle to describe the existence of legal traditions and the extent to which these dynamically adjust to the contemporary era.

In section 4.2 we explain what we mean by the private ordering ideal, and how this links to our general narrative of a spirit of a merchant-orientated law of international commercial contracts.

\subsection{Private Ordering in Commercial Contracting}

A privately ordered system is one which is governed by norms generated by the participants of that system (endogenously generated, 'from the bottom up'), rather than those imposed by a central sovereign State (exogenously generated, 'from the top down'). The idea is a stateless system of norms, existing in the practices of a community or market of participants. This is the counternarrative to the claim made in Hobbes's Leviathan that in the absence of a central

\footnotetext{
34 Ralf Michaels, 'Legal Medievalism in Lex Mercatoria Scholarship' (2012) 90 Tex L Rev 259, 264 using the terminology of Nicholas HD Foster, 'Foundation Myth as Legal Formant: The Medieval Law Merchant and the New Lex Mercatoria' [2005] Forum Historiae Iuris <https://forhistiur.de/2005-03 -foster/> accessed 18 May 2020.

35 Michaels, 'Legal Medievalism' (n 34) 267 (emphasis removed).

36 Trakman (n 21) chs 1-3.

37 Berger (n 10).
} 
sovereign, society would devolve into a 'war of all against all'. ${ }^{38}$ There is also a strong link to the theory of legal pluralism here, ${ }^{39}$ particularly if the claim is made that the privately ordered system is governed according to norms which have the force of law for those participants, and that such a system exists in parallel to the existent State law.

There is an extensive literature on private ordering, most of which is of a socio-legal nature. ${ }^{40}$ Many of the key studies originate from America, such as Bernstein's empirical investigation of the New York diamond industry, ${ }^{41}$ the US grain industry, ${ }^{42}$ and the US cotton industry. ${ }^{43}$ Other examples are the study of cattle rancher norms in Shasta county, California by Ellickson, ${ }^{44}$ and the seminal work on the 'non-use of contract' by Macaulay. ${ }^{45}$ There are also published studies from other parts of the world, such as Beale and Dugdale's early article on the contracting habits of engineering manufacturers in the $\mathrm{UK},{ }^{46}$ or Deakin, Lane and Wilkinson's chapter on inter-firm relations in Britain, Germany and Italy. ${ }^{47} \mathrm{In}$ addition, there are studies of developing economy markets in Africa, ${ }^{48}$ as well as in $\mathrm{Asia},{ }^{49}$ which draw on the fact that informal economies are normally ordered by market participants rather than by the State.

The examples above may describe contexts which are partially removed from the travelling merchants of the lex mercatoria, yet trade customs and commercial practices developed during this era still characterise aspects of contemporary commercial law. This suggests a system devised at least in part from the bottom up. In the context of a contemporary or 'new' lex mercatoria, Berger identifies bodies such as UNIDROIT, the United Nations Commission on International Trade Law (UNCITRAL) and the Organisation for the Harmonisation of Business Law in Africa (OHADA) as key examples of supra-national entities which create the contemporary model laws that govern international commercial contracts and the resolution of disputes thereunder. ${ }^{50}$ Since these bodies exist independently of any particular State and create

38 Thomas Hobbes, Leviathan (first published 1651, OUP 1998) ch XIV.

39 For the theory of legal pluralism, see eg: John Griffiths, 'What Is Legal Pluralism?' (1986) 24 J Legal Plur 1; Sally Engle Merry, 'Legal Pluralism' (1988) 22 L \& Soc’y Rev 869.

40 For an overview, see Barak D Richman, 'Firms, Courts and Reputation Mechanisms: Towards a Positive Theory of Private Ordering' (2004) 104 Colum L Rev 2328.

${ }^{41}$ Lisa Bernstein, 'Opting out of the Legal System: Extralegal Contractual Relations in the Diamond Industry’ (1992) 21 JLS 115.

42 Lisa Bernstein, 'Merchant Law in a Merchant Court: Rethinking the Code's Search for Immanent Business Norms’ (1996) 144 U Pa L Rev 1765.

43 Lisa Bernstein, 'Private Commercial Law in the Cotton Industry: Creating Cooperation through Rules, Norms and Institutions’ (2001) 99 Mich L Rev 1724.

44 Robert C Ellickson, Order Without Law: How Neighbors Settle Disputes (HUP 1991).

45 See, in particular, Stewart Macaulay, 'Non-Contractual Relations in Business: A Preliminary Study' (1963) 28 Am Soc Rev 55.

46 Hugh Beale and Tony Dugdale, 'Contracts between Businessmen: Planning and the Use of Contractual Remedies’ (1975) 2 Brit J L \& Soc 45.

47 Simon Deakin, Christel Lane and Frank Wilkinson, 'Contract Law, Trust Relations, and Incentives for Co-operation: A Comparative Study' in Simon Deakin and Jonathan Michie (eds), Contracts, Co-operation, and Competition (OUP 1997).

${ }_{48}$ Marcel Fafchamps, 'The Enforcement of Commercial Contracts in Ghana' (1996) 24 World Dev 427; Sally Falk Moore, 'Law and Social Change: The Semi-Autonomous Social Field as an Appropriate Subject of Study' (1973) 7 L \& Soc'y Rev 719.

49 John McMillan and Christopher Woodruff, 'Dispute Resolution without Courts in Vietnam' (1999) 15 J L Econ \& Org 637.

50 Berger (n 10) 43-46. 
rules which parties may choose of their own volition, there is a strong element of merchant ordering involved in both the processes of norm creation and the adoption thereof. The result is a system of private law-making and private governance, existing at supra-national level. ${ }^{51}$

From a contract theory point of view, the idea of privately ordered transactions is generally in line with the high place given to party autonomy in liberal market economies. ${ }^{52}$ Morgan has cogently argued in favour of minimalism in the realm of commercial contract regulation, on the grounds that international commercial parties will engage in sophisticated negotiation before contracting, which allows them to contract out of any undesired rules. ${ }^{53}$ Coupled with the ability to choose a substantive regime of law via a choice of law clause, Morgan's point rests on the argument that parties will gravitate to the system of law best suited to the economics of their transaction. ${ }^{54}$ The fact that he is primarily describing English contract law reinforces the view that this is a common choice of governing regime for international parties, bringing much work to the London courts. ${ }^{55}$ Indeed, the ideal that commercial practice should drive commercial law has long characterised extra-judicial commentary in English law. ${ }^{56}$

What then of the antithesis of private ordering, namely State regulation? Or, put in socio-legal terms: to what extent does politics interfere with the ordering of international economic transactions? Since private ordering and State regulation exist on a continuum in any form of commercial contracting, this is likely to be a contextual determination. Rules of private international law, as well as of the jurisdiction in which a dispute is heard, will play a role here. Since these are questions of context, we leave them to the description of our various authors in the chapters which follow. We invite you to share in the array of perspectives offered in the pages which follow.

\footnotetext{
51 ibid 40-51.

52 One of the key works on liberal contract theory is Charles Fried, Contract as Promise: A Theory of Contractual Obligation (2nd edn, OUP 2015).

53 Jonathan Morgan, Contract Law Minimalism (CUP 2013) ch 6.

54 ibid ch 9.

55 ibid 182. Statistics supporting this claim are quoted and discussed in Roger Halson and David Campbell, 'Harmonisation and Its Discontents: A Transaction Costs Critique of a European Contract Law' in James Devenney and Mel Kenny (eds), The Transformation of European Private Law: Harmonisation, Consolidation, Codification or Chaos? (CUP 2013).

56 Lord Devlin, 'The Relation between Commercial Law and Commercial Practice' (1951) 14 MLR 249; Lord Goff, 'Commercial Contracts and the Commercial Court' [1984] LMCLQ 382; Lord Steyn, 'Contract Law: Fulfilling the Reasonable Expectations of Honest Men' (1997) 113 LQR 433.
} 